\title{
Collagen Alpha-3(IV) Chain
}

National Cancer Institute

\section{Source}

National Cancer Institute. Collagen Alpha-3(IV) Chain. NCI Thesaurus. Code C26002.

Collagen alpha-3(IV) chain (1670 aa, 162 kDa) is encoded by the human COL4A3 gene.

This protein plays a role in the formation of basement membranes. 